\title{
Empirical Study on Interaction Evaluation Model of Informatization and Greenization Based on Coupling Theory
}

\author{
Liangwen Yue ${ }^{1,2, a}$, Menggang $\mathrm{Li}^{1}$ \\ ${ }^{1}$ China Center for Industrial Security Research, Beijing Jiaotong University; \\ No.3, Shangyuancun, Haidian District, Beijing, 100044, P.R.China. \\ ${ }^{2}$ Beijing Center for Industrial Security and Development Research. \\ aliangwenylw@163.com.
}

Keywords: informatization, greenization, coupling theory, sustainable development, green economy

\begin{abstract}
This paper contructed an interaction evaluation model of informatization and greenization based on the coupling theory in physics;and gave an empirical test and analysis on the support of Chinese provincial regional data for the year 2014.Study results confirms:the interaction evaluation model of informatization and greenization of this paper contructed is a scientific and comprehensive evaluation model of coincidencing the idea of sustainable development.The model has considerable significance theoretical innovation and practical application value,can evaluat and analyz availably the interaction between informatization and greenization,provide decision references and theory supports for a nation or a region to develop the wisdom economy and green economy,realize sustainable development.
\end{abstract}

\section{Introduction}

Informatization and greenization is the two practical way to bring about the drawbacks of the road of industrialization.Informatization and greenization is the two major support for the sustainable development of human society.It is difficult to realize the sustainable development lacking of any party.But the informatization and the greenization of the two theories and their practice is in the form of separate at home and abroad. Therefore,it has a significant theoretical and practical significance to research theory and practice of the interaction of Informatization and greenization,to take on a new road of industrialization and to realize sustainable development for the human society.Based on the above considerations,this paper contructed an interaction evaluation model of informatization and greenization based on the coupling theory in physics;and gave an empirical test and analysis on the support of Chinese provincial regional data for the year 2014 .

\section{The related research review}

\subsection{The literatures review of related problems}

The related literatures review of Informatization and Greenization are as follows.Xie etc. ${ }^{[1]}$ studied the convergence problem of Chinese industrializaion and informatization.Xu etc. ${ }^{[2]}$ explored the evolution mechanism industrialization,informatization,urbanization,agricultural modernization.At present, the concept of green growth with the highest citation rate is given by $\mathrm{OECD}^{[3]}$. Mathews and Reinert ${ }^{[4]}$ researched the role of renewable energy,clean technology and resource recycling systems on the green economy.Jakob and Edenhofer ${ }^{[5]}$ considered green growth is the economic growth model of enhancing "social welfare" and "human happiness".McKendry and Janos ${ }^{[6]}$ discussed green growth and sustainable development of industrial cities in developed countries.Tong etc. ${ }^{\text {[7] }}$ researched modeling China's green economy 2050.Zhang etc. ${ }^{[8]}$ explored greenization of venture capital and green innovation of Chinese entity industry.Liu etc. ${ }^{[9]}$ studied the evolution characteristics of greenization in China.Ding etc. ${ }^{[10]}$ give a general introduction on progress of coordinated 
development of industrialization,urbanization,agricultural modernization,informatization,and greenization in China, and other literatures,etc.

\subsection{Limitations of existing research}

(1)The research on the informatization needs to be further deepened at home and abroad.

(2) The research on the greenization is at the initial stage, and the research is not deep enough, and the research has not formed theoretical system.

(3)The interaction research of informatization and greenization is less, and it is difficult to guide the practice.

This study made up for these shortcomings.

\section{Interaction evaluation model of informatization and greenization}

\subsection{Interaction evaluation indicators system of informatization and greenization}

This paper contructed an interaction evaluation indicator of informatization and greenization, Table 1 is the evaluation indicators system. In this paper, we use AHP (Analytic Hierarchy Process) Method to synthesize 5 indicators(Index of post and telecommunications service,Computer ownership rate,Telephone penetration rate,Internet penetration rate,Electronic information industry specific gravity) into informatization comprehensive index. Similarly, we use AHP Method to synthesize 5 indicators (Renewable energy power generation ratio, Per capita sulfur dioxide emissions, Investment proportion of environmental pollution government, GDP energy intensity, Forest coverage) into greenization comprehensive index.

Table 1 Interaction evaluation indicators system of informatization and greenization

\begin{tabular}{|c|c|c|c|}
\hline & $\begin{array}{l}\text { Informatization and } \\
\text { Greenization }\end{array}$ & evaluation indicator & Concrete representation \\
\hline \multirow{10}{*}{$\begin{array}{l}\text { Interaction } \\
\text { degree of } \\
\text { informatization } \\
\text { and } \\
\text { greenization }\end{array}$} & \multirow[t]{5}{*}{$\begin{array}{l}\text { Informatization } \\
\text { comprehensive index }\end{array}$} & $\begin{array}{l}\text { Index of post and } \\
\text { telecommunications } \\
\text { service }\end{array}$ & $\begin{array}{l}\text { Number of Posts and telecommunications business } \\
\text { volume/post and telecommunications industry } \\
\text { practitioners(yuan/person) }\end{array}$ \\
\hline & & Computer ownership rate & $\begin{array}{l}\text { Computer ownership rate per hundred persons } \\
\text { (tai/hundred persons) }\end{array}$ \\
\hline & & $\begin{array}{l}\text { Telephone penetration } \\
\text { rate }\end{array}$ & $\begin{array}{l}\text { Telephone penetration rate per hundred } \\
\text { persons(bu/hundred persons) }\end{array}$ \\
\hline & & Internet penetration rate & $\begin{array}{l}\text { Internet penetration rate per hundred } \\
\text { persons(Percentage) }\end{array}$ \\
\hline & & $\begin{array}{l}\text { Electronic information } \\
\text { industry specific gravity }\end{array}$ & $\begin{array}{l}\text { Electronic information industry accounted for } \\
\text { GDP(percentage) }\end{array}$ \\
\hline & \multirow[t]{5}{*}{$\begin{array}{l}\text { greenization } \\
\text { comprehensive index }\end{array}$} & $\begin{array}{l}\text { Renewable energy power } \\
\text { generation ratio }\end{array}$ & $\begin{array}{l}\text { Renewable energy power generation accounts for the } \\
\text { proportion of total energy power } \\
\text { generation(percentage) }\end{array}$ \\
\hline & & $\begin{array}{l}\text { Per capita sulfur dioxide } \\
\text { emissions }\end{array}$ & $\begin{array}{l}\text { Annual average sulfur dioxide emissions per } \\
\text { capita(ton/person) }\end{array}$ \\
\hline & & $\begin{array}{l}\text { Investment proportion of } \\
\text { environmental pollution } \\
\text { government }\end{array}$ & $\begin{array}{l}\text { Environmental pollution government investment } \\
\text { accounted for GDP(percentage) }\end{array}$ \\
\hline & & GDP energy intensity & $\begin{array}{l}\text { Ten thousand yuan GDP energy consumption(tons of } \\
\text { standard coal) }\end{array}$ \\
\hline & & Forest coverage & Regional annual average forest coverage (percentage) \\
\hline
\end{tabular}

\subsection{Coupling degree model and coupling coordination degree model}

In this paper, the coupling theory of physics subject is introduced, which is used to explore the interactive development level evaluation of informatization and greenization.The model of coupling theory used in this paper is as follows.

\section{Coupling degree model}

Coupling degree model of physics subject is as follows:

$$
C_{n}=\left\{\frac{\left(U_{1} \times U_{2} \times \ldots \times U_{n}\right)}{\prod\left(U_{i}+U_{j}\right)}\right\}^{1 / n}
$$

In the above formula, $U_{1}, U_{2}, \ldots, U_{n}$ represent $n$ systems, $C_{n}$ represent Coupling degrees of the n systems 。 
There are two systems(informatization and greenization) in this paper,So,the coupling degree of the two systems is as follows:

$$
C=C_{2}=\left\{\frac{\left(U_{1} \times U_{2}\right)}{\left(U_{1}+U_{2}\right)^{2}}\right\}^{1 / 2}
$$

In the above formula, $U$ represent informatization comprehensive index, and $U_{2}$ represent greenization comprehensive index, $C_{2}$ represent coupling degree index $\mathrm{C}$ of the two systems, $0 \leq C<1$.

\section{Coupling coordination degree model}

coupling degree index $\mathrm{C}$ express two system coupling degree, but it can't reflect the actual interaction and coordination degree of the two systems, such as: the informatization and greenization level of a region is low, but we can draw high coupling degree evaluation results,and this is not meaningful. Therefore, we need to introduce coupling coordination index D to measure the degree of interaction between the two systems.

$$
D=\sqrt{C \times T} \quad \text { （3） ; } T=\alpha u_{1}+\beta u_{2} \quad \text { （4）; }
$$

Among them, D represents coupling coordination index,expresses the degree of interaction of the systems.T represents comprehensive evaluation index of two systems,reflect the overall efficiency of the two systems. $\alpha$ and $\beta$ represent undetermined coefficients.Generally speaking,we think that informatization and greenization are equally important. So, $\alpha$ and $\beta$ values are the same,both are 0.5 .

\subsection{Interactive degree evaluation standard of informatization and greenization}

Coupling coordination index $\mathrm{D}$ is the indicator which measures the degree of interaction and coordination between informatization and greenization,the measuring standard is in Table 2 .

\begin{tabular}{|c|c|c|c|c|c|}
\hline $\begin{array}{l}\text { Interactive } \\
\text { development } \\
\text { phase } \\
\end{array}$ & $\begin{array}{l}\text { Coupling } \\
\text { coordination degree } \\
\text { of D value }\end{array}$ & Interaction type & $\begin{array}{l}\text { Interactive } \\
\text { development } \\
\text { phase }\end{array}$ & $\begin{array}{l}\text { Coupling } \\
\text { coordination } \\
\text { degree of D value }\end{array}$ & Interaction type \\
\hline \multirow{3}{*}{$\begin{array}{l}\text { Low level } \\
\text { interaction: } \\
\text { Very little } \\
\text { contact }\end{array}$} & $0.0000-0.9999$ & $\begin{array}{l}\text { Extreme lack of } \\
\text { interaction }\end{array}$ & \multirow{3}{*}{$\begin{array}{l}\text { Strengthen } \\
\text { interaction: } \\
\text { Running in } \\
\text { contact }\end{array}$} & $0.5000-0.5999$ & Reluctant interaction \\
\hline & $0.1000-0.1999$ & $\begin{array}{l}\text { Serious lack of } \\
\text { interaction }\end{array}$ & & $0.6000-0.6999$ & Primary interaction \\
\hline & $0.2000-0.2999$ & $\begin{array}{l}\text { Moderate lack of } \\
\text { interaction }\end{array}$ & & $0.7000-0.7999$ & $\begin{array}{l}\text { Intermediate } \\
\text { interaction }\end{array}$ \\
\hline \multirow{2}{*}{$\begin{array}{l}\text { Start interaction: } \\
\text { Contend with } \\
\text { each other }\end{array}$} & $0.3000-0.3999$ & $\begin{array}{l}\text { Slight lack of } \\
\text { interaction }\end{array}$ & \multirow{2}{*}{$\begin{array}{l}\text { High level } \\
\text { interaction: } \\
\text { Fusion and } \\
\text { symbiosis }\end{array}$} & $0.8000-0.8999$ & Good interaction \\
\hline & $0.4000-0.4999$ & $\begin{array}{l}\text { On the verge of lack } \\
\text { of interaction }\end{array}$ & & $0.9000-1.0000$ & $\begin{array}{l}\text { High quality } \\
\text { interaction }\end{array}$ \\
\hline
\end{tabular}

Table 2 Interactive degree evaluation standard of informatization and greenization

\section{Evaluation and analysis of the interactive degree of China's informatization and greenization}

Specific relevant data of China's informatization and greenization in 2014 whose each indicator is showed in table 1, is derived from China Statistical Yearbook(2015), Statistical Yearbook of Chinese various provincial regions in the year 2015,China economic information network statistics database, CNKI"Statistical database of China's economic and social development",People's Republic of China"national statistical database" and other relevant statistical data. According to the interaction evaluation model of informatization and greenization presented above, we got interactive degree evaluation results of China's informatization and greenization in 2014,the results are shown in table 3. 
Table 3 Interactive degree evaluation results of informatization and greenization of Chinese provincial regions in 2014

\begin{tabular}{|c|c|c|c|c|c|}
\hline $\begin{array}{l}\text { Geographical } \\
\text { district }\end{array}$ & $\begin{array}{l}\text { Provincial } \\
\text { region }\end{array}$ & $\begin{array}{l}\text { Coupling } \\
\text { degree index C }\end{array}$ & $\begin{array}{l}\text { Comprehensive } \\
\text { evaluation } \\
\text { index T }\end{array}$ & $\begin{array}{l}\text { Coupling } \\
\text { coordination } \\
\text { index D }\end{array}$ & Interactive degree evaluation \\
\hline North China & $\begin{array}{l}\text { Beijing } \\
\text { Tianjin } \\
\text { Hebei } \\
\text { Shanxi } \\
\text { Inner Mongolia }\end{array}$ & $\begin{array}{l}0.4992 \\
0.4937 \\
0.3895 \\
0.3648 \\
0.3621\end{array}$ & $\begin{array}{l}0.8295 \\
0.7928 \\
0.5942 \\
0.3986 \\
0.4137\end{array}$ & $\begin{array}{l}0.6435 \\
0.6256 \\
0.4811 \\
0.3813 \\
0.3870\end{array}$ & $\begin{array}{l}\text { Primary interaction } \\
\text { Primary interaction } \\
\text { On the verge of lack of interaction } \\
\text { Slight lack of interaction } \\
\text { Slight lack of interaction }\end{array}$ \\
\hline $\begin{array}{l}\text { Northeast } \\
\text { China }\end{array}$ & $\begin{array}{l}\text { Heilongjiang } \\
\text { Jilin } \\
\text { Liaoning }\end{array}$ & $\begin{array}{l}0.4382 \\
0.4359 \\
0.4430\end{array}$ & $\begin{array}{l}0.5793 \\
0.6328 \\
0.6591\end{array}$ & $\begin{array}{l}0.5038 \\
0.5252 \\
0.5404\end{array}$ & $\begin{array}{l}\text { Reluctant interaction } \\
\text { Reluctant interaction } \\
\text { Reluctant interaction }\end{array}$ \\
\hline East China & $\begin{array}{l}\text { Shanghai } \\
\text { Jiangsu } \\
\text { Zhejiang } \\
\text { Anhui } \\
\text { Fujian } \\
\text { Shandong } \\
\text { Jiangxi }\end{array}$ & $\begin{array}{l}0.4986 \\
0.4864 \\
0.4793 \\
0.4239 \\
0.4632 \\
0.4583 \\
0.4326\end{array}$ & $\begin{array}{l}0.8206 \\
0.7265 \\
0.7153 \\
0.4529 \\
0.6817 \\
0.6754 \\
0.4620\end{array}$ & $\begin{array}{l}0.6396 \\
0.5944 \\
0.5855 \\
0.4382 \\
0.5619 \\
0.5564 \\
0.4471\end{array}$ & $\begin{array}{l}\text { Primary interaction } \\
\text { Reluctant interaction } \\
\text { Reluctant interaction } \\
\text { On the verge of lack of interaction } \\
\text { Reluctant interaction } \\
\text { Reluctant interaction } \\
\text { On the verge of lack of interaction }\end{array}$ \\
\hline Central China & $\begin{array}{l}\text { Henan } \\
\text { Hubei } \\
\text { Hunan }\end{array}$ & $\begin{array}{l}0.4478 \\
0.4257 \\
0.4192\end{array}$ & $\begin{array}{l}0.5158 \\
0.6034 \\
0.5651\end{array}$ & $\begin{array}{l}0.4806 \\
0.5068 \\
0.4867\end{array}$ & $\begin{array}{l}\text { On the verge of lack of interaction } \\
\text { Reluctant interaction } \\
\text { On the verge of lack of interaction }\end{array}$ \\
\hline South China & $\begin{array}{l}\text { Guangdong } \\
\text { Guangxi } \\
\text { Hainan } \\
\end{array}$ & $\begin{array}{l}0.4725 \\
0.4068 \\
0.4391 \\
\end{array}$ & $\begin{array}{l}0.7482 \\
0.4360 \\
0.5398 \\
\end{array}$ & $\begin{array}{l}0.5946 \\
0.4211 \\
0.4869 \\
\end{array}$ & $\begin{array}{l}\text { Reluctant interaction } \\
\text { On the verge of lack of interaction } \\
\text { On the verge of lack of interaction }\end{array}$ \\
\hline $\begin{array}{l}\text { Southwest } \\
\text { China }\end{array}$ & $\begin{array}{l}\text { Chongqing } \\
\text { Sichuan } \\
\text { Guizhou } \\
\text { Yunnan } \\
\text { Tibet }\end{array}$ & $\begin{array}{l}0.4502 \\
0.4187 \\
0.3514 \\
0.3950 \\
0.3483\end{array}$ & $\begin{array}{l}0.6473 \\
0.4802 \\
0.3579 \\
0.3857 \\
0.3265\end{array}$ & $\begin{array}{l}0.5398 \\
0.4484 \\
0.3546 \\
0.3903 \\
0.3372\end{array}$ & $\begin{array}{l}\text { Reluctant interaction } \\
\text { On the verge of lack of interaction } \\
\text { Slight lack of interaction } \\
\text { Slight lack of interaction } \\
\text { Slight lack of interaction }\end{array}$ \\
\hline $\begin{array}{l}\text { Northwest } \\
\text { China }\end{array}$ & $\begin{array}{l}\text { Shaanxi } \\
\text { Gansu } \\
\text { Qinghai } \\
\text { Ningxia } \\
\text { Xinjiang }\end{array}$ & $\begin{array}{l}0.4365 \\
0.3816 \\
0.3528 \\
0.3275 \\
0.3749\end{array}$ & $\begin{array}{l}0.6153 \\
0.3127 \\
0.3376 \\
0.3214 \\
0.3682\end{array}$ & $\begin{array}{l}0.5182 \\
0.3454 \\
0.3451 \\
0.3244 \\
0.3715\end{array}$ & $\begin{array}{l}\text { Reluctant interaction } \\
\text { Slight lack of interaction } \\
\text { Slight lack of interaction } \\
\text { Slight lack of interaction } \\
\text { Slight lack of interaction }\end{array}$ \\
\hline
\end{tabular}

The data in table 3 are analysed as follows. In the interactive degree of China's provincial regional informatization and greenization in 2014, Beijing, Shanghai, Tianjin belong to the primary interaction. Guangdong, Jiangsu, Zhejiang, Fujian, Shandong, Liaoning, Chongqing, Jilin, Shaanxi,

Hubei, Heilongjiang belong to reluctant interaction.Hainan, Hunan, Hebei, Henan, Sichuan, Jiangxi,

Anhui, Guangxi are on the verge of lack of interaction. Yunnan, Inner Mongolia, Shanxi, Xinjiang,

Guizhou, Gansu, Qinghai, Tibet, Ningxia belong to the Slight lack of interaction.Overall, there are interactions in China's provincial regional informatization and greenization in 2014, but the degree and level of interaction is not high. At present, the informatization and greenization strategy which is implemented in China's national level, is an opportunity for the China's provincial region.Every province should hold this opportunity,vigorously promote the local area of informatization and greenization,and promote the interaction between informatization and greenization;to make informatization and greenization become the transformative power which promote the development level of the local economy,society,science and technology,and other aspects. This is a necessary way which is used to narrow the regional gap, to make China as a whole realize modernization.

\section{Conclusions}

This paper contructed an interaction evaluation model of informatization and greenization based on the coupling theory in physics;and gave an empirical test and analysis on the support of Chinese provincial regional data for the year 2014. Study results confirms:the interaction evaluation model of informatization and greenization of this paper contructed is a scientific and comprehensive evaluation model of coincidencing the idea of sustainable development.The model has considerable 
significance theoretical innovation and practical application value,can evaluat and analyz availably the interaction between informatization and greenization, provide decision references and theory supports for a nation or a region to develop the wisdom economy and green economy, realize sustainable development.

\section{Acknowledgements}

This study is supported by The National Natural Science Foundation Major International (Regional) Joint Program of China (No.71320107006); The National Social Science Foundation Key Projects of China (No.14AZD090).

\section{References}

[1]Xie K,Xiao J H,Zhou X B,Wu J P.Quality of Convergence between Industrializaion and Informatization in China[J].Economic Research Journal,2012,(1):4-16.

[2]Xu W X,Chen G L,Shu J J,et al.Research on formation and evolution mechanism of "Four Modernizations Synchronous Zone" based on spatial continuity[J].China Industrial Economics,2015,(5):18-31.

[3]OECD.Towards Green Growth[R].OECD Publishing,2011:1-144.

[4]Mathews J A,Reinert E S.Renewables,manufacturing and green growth Energy strategies based on capturing increasing returns[J].Futures,2014,61:13-22.

[5]Jakob M, Edenhofer O.Green growth, degrowth, and the commons [J].Oxford Review of Economic Policy, 2014, 30(3):447-468.

[6]McKendry C, Janos N.Greening the industrial city: equity, environment, and economic growth in Seattle and Chicago [J].Int Environ Agreements, 2015, 15:45-60.

[7]Tong H F, Yang Y,Wang J Y,Feng Y.Modeling China's Green Economy 2050:Scenario Analysis Based on the System Dynamics Model[J].China Soft Science,2015,(6):20-34.

[8]Zhang W, Jin Y G, Wang J P. Greenization of venture capital and green innovation of Chinese entity industry [J].Ecological Indicators, 2015, 51:31-41.

[9]Liu K, Ren J L, Wang C X.The evolution characteristics and influencing factors of China's greenization [J].Urban problems, 2016, 249(4):11-17.

[10]Ding Z W,Zhang G S,Wang F Z,Kang J Y,Gao L.Progress on quantitative evaluation of coordinated development ofindustrialization,urbanization,agricultural modernization,informationization,and greenization in China and reflections[J].Progress in Geography,2016,35(1):4-13. 